\title{
A Study on Correlation and Path Coefficient Analysis for Yield and Yield Contributing Traits in Maintainer (B lines) Lines of Hybrid Rice (Oryza sativa L.)
}

\author{
B. Kiranmayee, Ch. Damodar Raju*, K. B. Kempa Raju and M. Balaram \\ Department of Genetics and Plant Breeding, College of Agriculture, Prof. Jayashankar \\ Telangana State Agricultural University, Rajendranagar, Hyderabad-030, Telangana, India \\ *Corresponding author
}

\section{A B S T R A C T}

\begin{tabular}{|l|}
\hline K e y w o r d s \\
$\begin{array}{l}\text { Correlation and Path } \\
\text { Coefficient, Hybrid Rice } \\
\text { (Oryza sativa L.) }\end{array}$ \\
\hline Article Info \\
\hline $\begin{array}{l}\text { Accepted: } \\
\text { 20 May } 2018 \\
\text { Available Online: } \\
\text { 10 June } 2018\end{array}$ \\
\hline
\end{tabular}

\section{Introduction}

Cereals contribute to major dietary intake of the people. Among the cereals, rice (Oryza sativa L.) is the major staple cereal which fulfills 60 percent dietary requirement, 20 percent calorie and 14 percent protein requirement of the world's population. (Khush, 2005; Amirjani, 2011).

In the present decade, the rise in population $(1.8 \%)$ is overtaking the rise in rice production $(1.5 \%)$. The present world population is 6.3 billion which is likely to reach 8.5 billion by 2030. Out of this, 5 billion people will be rice consumers and there is a need of $38 \%$ more rice by 2030 . Since the yield levels of semi- dwarf rice varieties of the Green Revolution era have plateaued, there is an immense need to take the best advantage of anyother most feasible solution to increase the availability of this staple grain to the population of our country. With the ever-increasing rate of population, the demand for rice is increasing rapidly. Among the limited options available, hybrid technology is the only practically proven, sustainable and eco-friendly technology currently available for stepping up rice production significantly. (Sheeba et al., 2009). Hybrid rice has clearly shown an yield advantage of 1-1.5 tones ha ${ }^{-1}$ (20 to $30 \%$ ) over conventionally bred modern varieties (Virmani et al., 2003). Therefore, the introduction of hybrids and popularization of 
their production technology are feasible and readily adoptable to achieve targeted production.

Hybrid rice is developed by exploiting the phenomenonof heterosis. Heterosis or hybrid vigor is a phenomenon in which an F1 hybrid has superior performance over its parents. The value of heterosis relative to mid and better parent in rice for yield and its components characters were studied by many investigators, such as Reddy et al., (2012) and Gnanamalar and Vivekanandan (2013). The success of any breeding programme depends on the choice of right parents for hybridization programme. Selection of the most worthy parental lines forms an important part of hybrid rice breeding program.

Selection for better yielding parents would be the ultimate objective for any breeder. But yield being a complex and a trait with low heritability, cannot be selected directly. The efficiency of selection for yield mainly depends on the direction and magnitude of association between yield and its component characters and also among themselves. (Srijan et al., 2016). Correlation and path coefficient analysis provides a better insight of association between the characters governing yield. Correlation analysis provides information on the nature and extent of association between pairs of metric traits and helps in selection for the improvement of the character. Since correlation gives only the relation between two variables while the path coefficient analysis allows separation of the direct effect and their indirect effects through other attributes by partitioning the correlations (Wright, 1921), both correlation and path analysis have been included in the present study. Keeping in view the above mentioned facts, the present study was conducted to understand the correlation between various yield contributing traits in 100 maintainer lines of hybrid rice. (Oryza sativa L.)

\section{Materials and Methods}

The experiment was conducted at Indian Institute of Rice Research, Rajendrangar, Hyderabad during Kharif, 2017. Hundred selected maintainer lines formed a part of this study. The experiment was carried out in a randomized block design with three replications. All the necessary agronomic practices were carried out timely during the study. Data was collected from five randomly selected plants from each row and the observations viz., days to fifty per cent flowering, plant height, panicle length, panicle weight, number of productive tillers per plant, number of grains per panicle, spikelet fertility percentage, 1000 grain weight and grain yield per plant and per day productivity were included in the study. The analysis of variance was done using WINDOSTAT software. Normal Pearson's correlation was calculated using WINDOSTAT software. Genotypic and phenotypic correlation coefficients were calculated following snedechor et al., Path coefficient analysis was estimated according to the method suggested by Dewey and Lu.

\section{Results and Discussion}

The analysis of variance depicted highly significant variation among the hybrids for all the characters studied. Simple correlation analysis among yield and its contributing characters are shown in Table1. An analysis on character association, to assess the relationship among yield and its components and to have an insight into the causes for higher yield in hybrids based on the data recorded on 100 maintainer lines was done.

Yield per plant showed a positive significant correlation with per day productivity $\left(0.95^{* *}\right)$.Positive non-significant association was observed for this trait with days to fifty percent flowering (0.09), number of productive tillers $(0.16)$, panicle length $(0.03)$, 
panicle weight (0.12), number of grains per panicle (0.01). This indicates that all these characters are important for yield improvement. Hence, these characters could be considered as criteria for selection for higher yield as these were mutually and directly associated with grain yield. It showed a negative non-significant association with plant height $(-0.05)$, test weight $(-0.008)$ and per day productivity (-0.11). Similar results were reported by Rao et al., (2014), Kishore et $a l .$, (2015) for days to fifty percent flowering, Aris et al., (2010), Naseem et al., (2014) for plant height, Binod et al., (2016) for number of productive tillers per plant, Seyoum et al., (2012), Kishore et al., (2015) for panicle length, Souroush et al., (2004) for panicle weight, Aris et al., (2010) for number of grains per panicle, Ravinder Babu et al., (2012) for test weight, Srijan et al., (2016) for per day productivity.

The character days to $50 \%$ flowering expressed a positive significant association with plant height $\left(0.44^{* *}\right)$, panicle length $\left(0.33^{* *}\right)$, number of grains per panicle $(0.344 * *)$. Similar results were reported by Ravinder Babu et al., (2012), Srijan et al., (2016), Srikanth et al., (2017) for plant height ; Satish et al., (2009), Srijan et al., (2016) for panicle length and Eswara Reddy et al., (2013), Rao et al., (2014) for number of grains per panicle. It showed positive non-significant association with number of productive tillers per plant (0.15), panicle weight (0.16), yield per plant (0.09). Similar results were reported by Rao et al., (2014), Kishore et al., (2015) for yield per plant, Satish et al., (2009) for number of productive tillers, Awaneet and Senapati (2012) for panicle weight. This trait expressed negative non-significant association with test weight $(-0.09)$, spikelet percentage ($0.11)$, per day productivity (-0.18). Similar results were reported by Satish et al., (2009) and Nandan et al., (2010) for test weight; Mishu et al., (2016) for spikelet percentage.
Plant height expressed positive significant association with panicle length $(0.28$, panicle weight $\left(0.26^{* *}\right)$, number of grains per panicle (0.24). Similar results were reported by Satish et al., (2009), Ravinder Babu et al., (2012), Eswar Reddy et al., (2013), Anis et al., (2016), Touhiduzzaman et al., (2016), Srijan et al., (2016), Mamata et al., (2017) Rajendra Prasad et al., (2017), Soumiya et al., (2017) for panicle length and Anis et al., (2016), Rajendra Prasad et al., (2017) for panicle weight. The results were in conformity with Satish et al., (2009), Eswar Reddy et al., (2013), Touhiduzzaman et al., (2016), Soumiya et al., (2017) for number of grains per panicle. It showed positive non-significant association with test weight (0.08). Similar results were reported by Golam et al., (2015), Mishu et al., (2016). Negative non-significant association was showed with number of productive tillers $(-0.06)$, spikelet percentage $(-0.09)$, per day productivity $(-0.17)$, yield per plant $(-0.05)$ by this trait. Similar results were reported by Aris et al., (2010), Naseem et al., (2014) for yield per plant. Naseem et al., (2014) reported the similar results for number of productive tillers per plant, Nandeshwar (2010) for spikelet fertility.

Number of productive tillers per plant showed a positive significant association with number of grains per panicle $(0.27 * *)$. Similar results were reported by Ravinder Babu et al., (2012). It showed positive non-significant association with panicle weight (0.50), per day productivity $(0.11)$, yield per plant $(0.16)$.

Similar results were reported by Binod et al., (2016) for grain yield per plant; Ranwake and Amarasighe (2014) for panicle weight and number of grains per panicle. This trait exhibited negative non-significant association with panicle length $(-0.01)$, test weight $(-0.09)$, spikelet fertility $(-0.003)$. The results were in accordance with those reported by Satish et al., (2009), Ravinder Babu et al., (2012) for 
test weight and Binod et al., (2016) for panicle length. Panicle length showed positive significant association with number of grains per panicle $\left(0.22^{*}\right)$. Similar results were reported by Satish et al., (2009), Eswara Reddy et al., (2013), Gopikannan et al., (2013), Naseem et al., (2014), Touhiduzzaman et al., (2016). It expressed positive nonsignificant association with panicle weight $(0.14)$, test weight $(0.10)$, yield per plant (0.03). Similar results were reported by Seyoum et al., (2012), Kishore et al., (2015) for yield per plant; Nandeshwar (2010), Ranwake et al., (2014).This trait depicted negative non-significant association with spikelet fertility (-0.15) and per day productivity $(-0.06)$.

Panicle weight showed positive significant association with number of grains per panicle (0.22). Similar results were reported by Nandeshwar et al., (2010), Ranwake et al., (2014). It expressed positive non-significant association with spikelet fertility (0.03), per day productivity (0.07), yield per plant (0.12). Similar results were reported by Bastian et al., (2000), Souroush et al., (2004) for yield per plant. This trait showed negative nonsignificant association with test weight (0.01). Similar results were reported by Moosavi et al., (2015). The number of grains per panicle showed positive non-significant association with spikelet fertility (0.003) and yield per plant (0.01). Similar result was expressed by Aris et al., (2010). It expressed negative significant association with test weight ($0.34 * *)$. It showed negative non-significant association with per day productivity $(-0.05)$.

Test weight depicted positive non-significant association with spikelet fertility (0.02). It showed negative non-significant association with per day productivity $(-0.007)$ and yield per plant (-0.008). These results were in conformity with Ravinder Babu et al., (2012) for yield per plant (2012). Spikelet fertility exhibited negative non-significant association with per day productivity (-0.098) and yield per plant (-0.11). Per day productivity exhibited positive significant association with yield per plant $\left(0.95^{* *}\right)$. Similar results were reported by Srijan et al., (2016).From the study it was concluded that there is change in the association between different yield components, the trait per day productivity is very crucial for higher yields, as it exhibited significant positive correlations with grain yield per plant. The other important traits to be considered are plant height and panicle length. Many times, in rice, semi tall plant types (110$115 \mathrm{~cm}$ ) with sturdy culm (non- lodging) would yield better than the dwarf ones.

Based on the data recorded on 100 maintainer lines, the direct and indirect effects of yield attributing traits were estimated and results are presented in Table $2 \&$ Fig. $1 \& 2$. The days to 50 per cent flowering had direct phenotypic positive effect (0.08) on single plant yield and the correlation between days to 50 per cent flowering and single plant yield was positive and non-significant. Similar results were reported by Ratna et al., (2015), Ravinder Babu et al., (2012), Binod et al., (2016), Srijan et al., (2016) for direct phenotypic positive effect on yield. The correlation was positive and non-significant mainly due to positive indirect effect through plant height (0.10), number of productive tillers (0.02), panicle length (0.08), panicle weight (0.03), number of grains per panicle (0.08). Similar results were reported by Srijan et al., (2016) for panicle weight, Satish et al., (2009), Srijan et al., (2016) for number of productive tillers, by Rajendra Prasad et al., (2017) for all the traits mentioned. This trait exhibited negative indirect phenotypic effects on single plant yield through test weight $(-0.02)$, spikelet fertility (-0.02) and per day productivity (0.04). Similar results were reported by Ratna et al., (2015) for test weight, Mishra et al., (2014) for spikelet fertility. 
Table.1 Pooled genotypic correlation coefficient analysis of single plant grain yield and yield contributing characters in rice

\begin{tabular}{|c|c|c|c|c|c|c|c|c|c|c|}
\hline Character & $\begin{array}{l}\text { Days to } \\
50 \% \\
\text { flowering }\end{array}$ & $\begin{array}{l}\text { Plant } \\
\text { height } \\
(\mathrm{cm})\end{array}$ & $\begin{array}{l}\text { Number of } \\
\text { productive } \\
\text { tillers per } \\
\text { plant }\end{array}$ & $\begin{array}{l}\text { Panicle } \\
\text { length } \\
(\mathrm{cm})\end{array}$ & $\begin{array}{l}\text { Panicle } \\
\text { weight (g) }\end{array}$ & $\begin{array}{l}\text { Number } \\
\text { of grains } \\
\text { per } \\
\text { panicle }\end{array}$ & $\begin{array}{l}\text { Test } \\
\text { weight(g) }\end{array}$ & $\begin{array}{l}\text { Spikelet } \\
\text { fertility }\end{array}$ & $\begin{array}{l}\text { Per day } \\
\text { productivity }\end{array}$ & $\begin{array}{l}\text { Yield per } \\
\text { plant }\end{array}$ \\
\hline $\begin{array}{l}\text { Days to } 50 \% \\
\text { flowering } \\
\end{array}$ & 1.00000 & $0.44066^{* * *}$ & 0.15040 & $0.33582 * *$ & 0.16290 & $0.34443 * *$ & -0.09483 & -0.11692 & -0.18285 & 0.09967 \\
\hline Plant height $(\mathrm{cm})$ & & 1.00000 & -0.6967 & $0.28670 * *$ & $0.26297 * *$ & $0.24664 *$ & 0.08871 & -0.09907 & -0.17135 & -0.05101 \\
\hline $\begin{array}{l}\text { Number of } \\
\text { productive tillers }\end{array}$ & & & 1.00000 & -0.01956 & 0.05065 & $0.27763 * *$ & -0.09787 & -0.00356 & 0.11819 & 0.16389 \\
\hline $\begin{array}{l}\text { Panicle length } \\
\text { (cm) }\end{array}$ & & & & 1.00000 & 0.14417 & $0.22387 *$ & 0.10285 & -0.15616 & -0.06772 & 0.03022 \\
\hline Panicle weight(g) & & & & & 1.00000 & $0.22268^{*}$ & -0.01636 & 0.03540 & 0.07601 & 0.12428 \\
\hline $\begin{array}{l}\text { Number of grains } \\
\text { per panicle }\end{array}$ & & & & & & 1.00000 & $-\overline{0.34015^{* *}}$ & 0.00313 & -0.05934 & 0.01377 \\
\hline Test weight (g) & & & & & & & 1.00000 & 0.02230 & -0.00077 & -0.00816 \\
\hline $\begin{array}{l}\text { Spikelet } \\
\text { percentage }\end{array}$ & & & & & & & & 1.00000 & -0.09987 & -0.11941 \\
\hline $\begin{array}{l}\text { Per day } \\
\text { productivity } \\
\text { (g/day) }\end{array}$ & & & & & & & & & 1.00000 & $0.95360 * *$ \\
\hline Yield per plant(g) & & & & & & & & & & 1.00000 \\
\hline
\end{tabular}

* Significant at 5 per cent level; ** Significant at 1 per cent level 
Table.2 Phenotypic (P) and Genotypic (G) Path coefficient analysis of yield and yield contributing characters in maintainer lines of hybrid rice

\begin{tabular}{|c|c|c|c|c|c|c|c|c|c|c|}
\hline Character & & $\begin{array}{l}\text { Days to } \\
50 \% \text { flowering }\end{array}$ & $\begin{array}{l}\text { Plant } \\
\text { height } \\
\text { (cm) }\end{array}$ & $\begin{array}{l}\text { no. of } \\
\text { productive } \\
\text { tillers }\end{array}$ & $\begin{array}{l}\text { Panicle } \\
\text { length } \\
\text { (cm) }\end{array}$ & $\begin{array}{l}\text { Painicle } \\
\text { weight(g) }\end{array}$ & $\begin{array}{l}\text { No. of } \\
\text { grains per } \\
\text { panicle }\end{array}$ & $\begin{array}{l}\text { Test } \\
\text { weight } \\
(\mathrm{g})\end{array}$ & $\begin{array}{l}\text { Spikelet } \\
\text { fertility }\end{array}$ & $\begin{array}{l}\text { Per day } \\
\text { productivity } \\
\text { (g/day) (g) }\end{array}$ \\
\hline \multirow[t]{2}{*}{ Days to $50 \%$ flowering } & $\mathbf{P}$ & 0.2579 & 0.1074 & 0.0260 & 0.0805 & 0.0342 & 0.0874 & -0.0222 & -0.0288 & -0.0425 \\
\hline & $\mathbf{G}$ & 0.2837 & 0.1304 & 0.0495 & 0.0987 & 0.0597 & 0.0987 & -0.0266 & -0.0338 & -0.0488 \\
\hline \multirow[t]{2}{*}{ Plant height } & $\mathbf{P}$ & -0.0027 & -0.0065 & 0.0003 & -0.0017 & -0.0012 & -0.0015 & -0.0005 & 0.0006 & 0.0009 \\
\hline & $\mathbf{G}$ & 0.0007 & 0.0016 & -0.0002 & 0.0005 & 0.0006 & 0.0004 & 0.0001 & -0.0002 & -0.0003 \\
\hline \multirow[t]{2}{*}{ No.of productive tillers } & $\mathbf{P}$ & 0.0007 & -0.0003 & 0.0065 & -0.0003 & 0.0002 & 0.0012 & -0.0008 & 0.0000 & 0.0005 \\
\hline & $\mathbf{G}$ & 0.0031 & -0.0019 & 0.0175 & -0.0009 & -0.0004 & 0.0057 & -0.0042 & 0.0002 & 0.0023 \\
\hline \multirow[t]{2}{*}{ Panicle length $(\mathrm{cm})$} & $\mathbf{P}$ & 0.0009 & 0.0007 & -0.0001 & 0.0028 & 0.0003 & 0.0006 & 0.0003 & -0.0004 & -0.0001 \\
\hline & $\mathbf{G}$ & 0.0039 & 0.0034 & -0.0006 & 0.0113 & 0.0022 & 0.0026 & 0.0012 & -0.0018 & -0.0008 \\
\hline \multirow[t]{2}{*}{ Panicle weight(g) } & $\mathbf{P}$ & -0.0009 & -0.0013 & -0.0003 & -0.0007 & -0.0067 & -0.0011 & -0.0001 & -0.0001 & -0.0006 \\
\hline & $\mathbf{G}$ & -0.0056 & -0.0097 & 0.0006 & -0.0051 & -0.0264 & -0.0083 & 0.0012 & -0.0015 & -0.0030 \\
\hline \multirow[t]{2}{*}{ no. of grains per panicle } & $\mathbf{P}$ & -0.0017 & -0.0012 & -0.0010 & -0.0011 & -0.0008 & -0.0051 & 0.0017 & 0.0000 & 0.0003 \\
\hline & $\mathbf{G}$ & -0.0020 & -0.0014 & -0.0018 & -0.0013 & -0.0018 & -0.0056 & 0.0020 & 0.0000 & 0.0004 \\
\hline \multirow[t]{2}{*}{ Test weight (g) } & $\mathbf{P}$ & -0.0004 & 0.0004 & -0.0006 & -0.0004 & 0.0000 & -0.0015 & 0.0046 & 0.0001 & 0.0001 \\
\hline & $\mathbf{G}$ & -0.0004 & 0.0004 & -0.0011 & 0.0005 & -0.0002 & -0.0016 & 0.0047 & 0.0001 & 0.0000 \\
\hline \multirow[t]{3}{*}{ Spikelet percentage } & $\mathbf{P}$ & 0.0000 & 0.0000 & 0.0000 & -0.0001 & 0.0000 & 0.0000 & 0.0000 & 0.0004 & 0.0000 \\
\hline & $\mathbf{G}$ & -0.0005 & -0.0004 & 0.0001 & -0.0006 & 0.0002 & 0.0000 & 0.0001 & 0.0041 & -0.0004 \\
\hline & $\mathbf{P}$ & -0.1656 & -0.1378 & 0.0701 & -0.0438 & 0.0902 & -0.0623 & 0.0139 & -0.0900 & 1.0043 \\
\hline $\begin{array}{l}\text { Per day } \\
\text { productivity(g/day) }\end{array}$ & G & -0.1737 & -0.1852 & 0.1316 & -0.0760 & 0.1132 & -0.0801 & 0.0102 & -0.0874 & 1.0090 \\
\hline \multirow[t]{2}{*}{ Yield per plant(g) } & $\mathbf{P}$ & 0.0881 & -0.0385 & 0.1011 & 0.0360 & 0.1163 & 0.0177 & -0.0032 & -0.1182 & 0.9627 \\
\hline & $\mathbf{G}$ & 0.1092 & -0.0628 & 0.1956 & 0.0270 & 0.1472 & 0.0116 & -0.0113 & -0.1203 & 0.9584 \\
\hline
\end{tabular}

Genotypic residual effect $=0.05 \quad$ Phenotypic residual effect $=0.10$

BOLD values are direct effects 
Fig.1 Simple genotypical path diagram for yield and its contributing traits

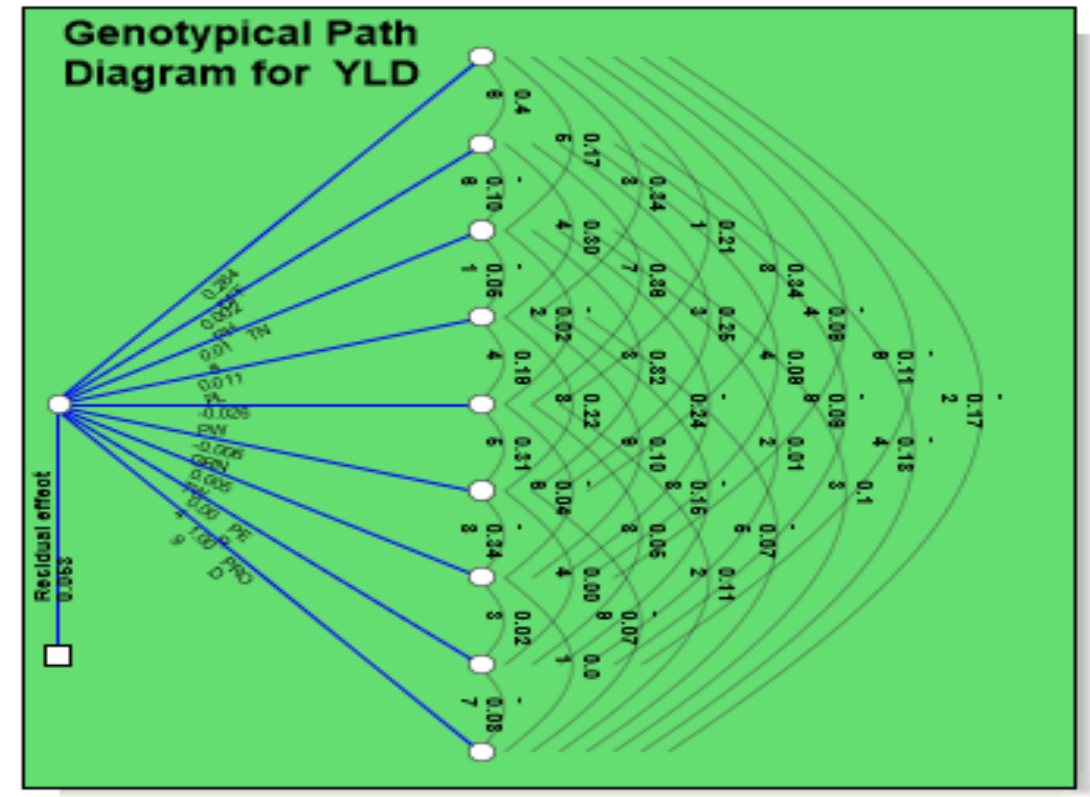

Fig.2 Simple phenotypical path diagram for yield and its contributing traits

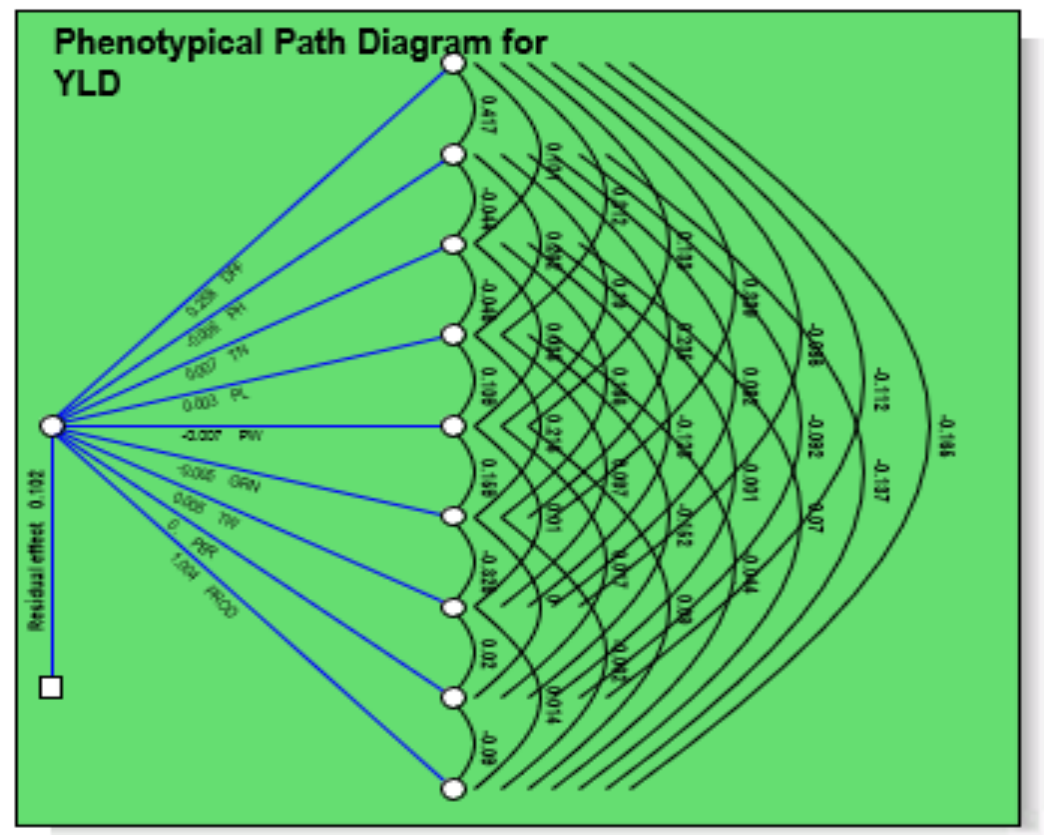

Plant height $(\mathrm{cm})$ had a phenotypic negative direct effect on single plant yield (-0.03), and the correlation with single plant yield was negative and non-significant. These results are in agreement with the findings of Aris et al., (2010), Ravinder Babu et al., (2012),
Eswar Reddy et al., (2013), Naseem et al., (2014), Ratna et al., (2015), Binod et al., (2016), Srijan et al., (2016). The correlation was negative and non-significant mainly due to indirect effect contribution through days to fifty percent flowering (-0.02), panicle length 
(-0.17), panicle weight $(-0.12)$, number of grains per panicle $(-0.15)$, test weight $(0.05)$. Similar results were reported by Aris et al., (2010) for number of grains per panicle and test weight and Binod et al., (2016) for test weight; Patel et al., (2014) for days to fifty percent flowering; Patel et al., (2014) for panicle length. This trait exhibited positive indirect phenotypic effects on single plant yield through number of productive tillers (0.03), spikelet fertility (0.06) and per day productivity (0.09). The results were in agreement with Aris et al., (2010), Rajendra Prasad et al., (2017) for number of productive tillers per plant, Kumar et al., (2015) for spikelet fertility.

Number of productive tillers per plant exhibited a phenotypic positive direct effect on single plant yield (0.10) while the correlation with single plant yield was also positive and significant. Similar results were reported by Aris et al., (2010), Gopikannan et al., (2013), Naseem et al., (2014), Binod et al., (2016), Srijan et al., (2016), Rajendra Prasad et al., (2017). The correlation was positive and non-significant mainly due to positive indirect effect contribution through days to 50 per cent flowering (0.07), panicle weight (0.02), number of grains per panicle (0.12), per day productivity (0.05). The similar results were reported by Rajendra Prasad et al., (2017) for panicle weight, Srijan et al., (2016) for days to fifty percent flowering, number of productive tillers; Patel et al., (2015) for number of grains per panicle. This trait exhibited negative indirect phenotypic effects on single plant yield through plant height $(-0.03)$, panicle length (0.03 ) and test weight (-0.08). Similar results were reported by Golam et al., (2015) for plant height, Ratna et al., (2015) for panicle length, Golam et al., (2015) for test weight.

Panicle length $(\mathrm{cm})$ had a low phenotypic positive direct effect on single plant yield
(0.03), and the correlation with single plant yield was also positive and non-significant. These results are in agreement with the findings of Ratna et al., (2015), Binod et al., (2016), Soumiya et al., (2017). The correlation was positive and non-significant mainly due to positive indirect effect contribution through days to fifty percent flowering (0.09), plant height (0.07), panicle weight (0.03), number of grains per panicle (0.06) and test weight (0.03). Similar results were reported by Satish et al., (2009), Binod et al., (2016) for plant height, Satish et al., (2009), Srijan et al., (2016) for days to fifty percent flowering, Srijan et al., (2016) for panicle weight, test weight, Kumar and Verma (2015) for number of grains per panicle. This trait exhibited negative indirect phenotypic effects on single plant yield through number of productive tillers $(-0.01)$, spikelet fertility $(-0.04)$ and per day productivity (-0.01). Similar results were reported by Ratna et al., (2015) for number of productive tillers per plant.

Panicle weight had direct positive phenotypic effect (0.11) on single plant yield and the correlation was positive non-significant. Similar results were reported by Cyprein et al., (2011), Srijan et al., (2016). This trait exhibited negative indirect phenotypic effects on single plant yield through days to fifty percent flowering (-0.09), plant height $(-0.13)$, number of productive tillers per plant $(-0.03)$, panicle length (-0.07), number of grains per panicle (-0.01), test weight (-0.01), spikelet fertility (-0.01), per day productivity $(-0.06)$. Similar results were reported by Awaneet et al., (2013) for plant height. Number of grains per panicle had direct phenotypic positive effect (0.01) on single plant yield. Similar results were reported by Eswara Reddy et al., (2013), Naseem et al., (2014), Binod et al., (2016). Its correlation with single plant yield was also positive and non-significant. The correlation between number of grains per 
panicle and single plant yield was positive and non-significant mainly due to positive indirect effect contribution through test weight (0.17), per day productivity (0.03). Similar results were reported by Patel et al., (2015) for test weight. This trait exhibited negative indirect phenotypic effects on single plant yield through days to fifty percent flowering (-0.17), plant height (-0.12), number of productive tillers $(-0.10)$, panicle length (-0.11) and panicle weight (-0.08). Similar results were reported by Rajamadhan et al., (2011) for days to fifty percent flowering, Naseer et al., (2015) for plant height. Patel et al., (2015) reported the similar results for number of productive tillers per plant, panicle length.

This trait showed direct negative phenotypic effect of test weight on single plant yield (0.03 ) and its correlation with grain yield was also negative non-significant. This result was similar to the one reported by Cyprien et al., (2011), Ravinder Babu et al., (2012). The correlation between test weight and single plant yield was negative mainly due to negative indirect effect influence through days to fifty percent flowering (-0.04), number of productive tillers (-0.06), number of grains per panicle (-0.15). Similar results were depicted by Srijan et al., (2016), Rajendra Prasad et al., (2017) for days to fifty percent flowering, Srijan et al., (2016) for number of productive tillers, Eswar Reddy et al., (2013) for number of grains per panicle.

This trait exhibited positive indirect phenotypic effects on single plant yield through plant height (0.04), panicle length (0.04), spikelet fertility (0.01), per day productivity (0.01). Similar results were reported by Rajendra Prasad et al., (2017) for panicle length, Golam et al., (2015) for plant height, Rahman et al., (2014) for panicle length, Dilruba et al., (2014) for spikelet percentage.
Spikelet fertility had direct negative phenotypic effect $(-0.11)$ on single plant yield and the correlation between spikelet fertility and single plant yield was negative and nonsignificant. Similar results were reported by Srijan et al., (2016). The correlation was negative mainly due to positive indirect contribution through panicle length (-0.01). Similar results were reported by Srijan et al., (2016), Rajendra Prasad et al., (2017). This trait did not exhibit any positive phenotypic indirect effect through other traits. Per day productivity showed the maximum contribution to direct positive phenotypic effect (0.96) on single plant yield, the correlation was positive significant. Similar results were reported by Srijan et al., (2016). The correlation was positive mainly due to positive indirect contribution through number of productive tillers (0.07), panicle weight (0.09), test weight (0.01). Similar results were reported by Srijan et al., (2016) for panicle weight, number of productive tillers, test weight. This trait exhibited negative indirect phenotypic effects on single plant yield through days to fifty percent flowering ($0.16)$, plant height $(-0.13)$, panicle length ($0.04)$, number of grains per panicle $(-0.06)$, per day productivity $(-0.09)$.

The association of different component characters among themselves and with yield is quite important for devising an efficient selection criterion for yield. The total correlation between yield and component characters may be sometimes misleading, as it might be an over-estimate or under-estimate because of its association with other characters. Hence, indirect selection by correlated response may not be sometimes fruitful. When many characters are affecting a given character, splitting the total correlation into direct and indirect effects of cause as devised by Wright (1921) would give more meaningful interpretation to the cause of association between the dependent variable 
like yield and independent variables like yield components. This kind of information will be helpful in formulating the selection criteria, indicating the selection for these characters is likely to bring about on overall improvement in single plant yield directly.

Path coefficient analysis revealed that per day productivity has the highest positive direct effect on grain yield followed by panicle weight and number of productive tillers being the most important characters which could be used as selection criteria for effective improvement on grain yield. Therefore, it is suggested that preference should be given to these characters in the selection programme to isolate superior lines with genetic potentiality for higher yield in rice genotypes.

\section{Acknowledgements}

Lead author earnest acknowledgment must go to his guides Dr. Ch. Damodar Raju, Dr. K.B.Kemparaju, for their scholastic guidance, unceasing interest, valuable knowledge and technical advice. I wish my sincere thanks to M.Balram for his moral support, cooperation and kindness during my study.

\section{References}

Amirjani, M.R. 2011. Effect of salinity stress on growth, sugar content, pigments and enzyme activity of rice. International Journal of Botany 7(1): 73-81.

Anis, G.B., Namaky, E.L., Ashkar, I.M., Barutçular, C., Sabagh, A. 2016. Yield potential and correlation analysis of some rice hybrids for yield and its component traits. Journal of Animal \&Plant Sciences. 30(2): 4748-4757.

Aris, H., Bambang, K., Supartopo, and Suwarno. 2010. Correlation analysis of agronomic characters and grain yield of rice for tidal swamp areas. Indonesian Journal of Agricultural Science. 11(1): 11-15.
Awaneet, K and Senapati, B.K. 2013. Genetic parameters and association studies for important quantitative traits in advanced lines of Sambamahsuri derivatives. Journal of Crop and Weed. 9(1): 156-163.

Binod, P.B., Niranjan, A., Sharma, S.N., Surendra, P. 2016. Variability, Correlation and Path Coefficient Analysis of Rice (Oryza sativa L.). International Journal of Scientific \& Engineering Research. 7(8).

Cyprien and Vinod Kumar. 2011. Correlation and Path Coefficient Analysis of rice cultivars data. Journal of Reliability and Statistical Studies. 4(2): 119-131.

Dewey, J.R and Lu, K.H. 1959. Correlation and path coefficient analysis of components of crested wheat grass seed production. Agronomy Journal. 51: 515-518.

Dilruba, K., Siddique, E., Umakanto, S., Md. Zakir, H and Jakia, S. 2014. Phenotypic and genotypic correlation co-efficient of quantitative characters and character association of aromatic rice. Journal of Bioscience and Agriculture Research. 1(01): 34-46.

Eswara Reddy, G., Suresh, B.G., Sravan, T. 2013. Correlation and path analysis for yield and yield attributes in rice (Oryza sativa L.) genotypes. International Journal of Plant Sciences. 8(2): 391-394.

Gnanamalar, R.P. and P. Vivekanandan. 2013. Heterosis for grain yield and grain quality traits in rice (Oryza sativa L.). Asian Journal of Plant Science and Research. 3(3):100-106.

Golam, S., Md. Harun-Ur-R, Shahanaz, P and Md. Sarowar, H. 2015. Correlation and Genotypes (Oryza sativa L.). Advances in Bioresearch. 6(4): 40-47.

Gopikannan, M., Ganesh, S.K. 2013. InterRelationship and Path Analysis in Rice (Oryza sativa L.) under Sodicity. Indian Journal of Science and Technology. 6(9).

Khush, G.S. 2005. What it will take to feed 5.0 billion rice consumers in 2030. Plant Molecular Biology. 59: 1-6.

Kishore, N.S., Srinivas, T., Nagabhushanam, U., Pallavi, M and Sameera, S.K. 2015. 
Genetic variability, correlation and path analysis for yield and yield components in promising rice (Oryza sativa L.) genotypes. Journal of Agriculture. 13(1): 99-108.

Kumar, A and Verma, O.P. 2015. Correlation and path coefficient analysis in certain quantitative traits in rice (Oryza sativa L.) under saline-alkaline condition. Research in Environment and Life Sciences. 8(3): 443-446.

Mamata, B., Monalisa, S.P., Bastia, D.N., and Chiranjeevi C. 2017. Correlation and Path Analysis Studies in Aerobic Rice. International Journal of Current Microbiology and Applied Sciences. 6(8): 2851-2856.

Mishra, V.K., Dwivedi, D.K and Pramila, P. 2014. Consequence of salinity on biological yield, grain yield and harvest index in rice (Oryza sativa L.) Cultivars. Environment \& Ecology. 32(3): 964968.

Mishu, F.K., Md. Rahman, W., Md. Abul, K.A., Biswas, B.K., Md. Aminul, I.T., Md. Omar, K., Md. Rafiqul, I and Md. Rakibul, A. 2016. Study on genetic variability and character association of aromatic rice (Oryza sativa L.) Cultivars. International Journal of Plant \& Soil Science. 9(1): 18.

Moosavi, M., Ranjbar, G., Zarrini, H.N and Gilani, A. 2015. Correlation between morphological and physiological traits and path analysis of grain yield in rice genotypes under khuzestan conditions. Biological Forum. 7(1): 43-47.

Nandan, R., Sweta and Singh, S.K. 2010. Character association and path analysis in rice (Oryza sativa L.) genotypes. World Journal of Agricultural Sciences. 6(2): 201-206.

Nandeshwar, B.C., Pal, S., Senapati, B.K and De, D.K. 2010. Genetic variability and character association among biometrical traits in F2 generation of some Rice crosses. Electronic Journal of Plant Breeding. 1(4): 758-763.

Naseem, I., Khan, A.S and Akhter, M. 2014. Correlation and path coefficient of some yield related traits in rice (Oryza sativa L.). International Journal of Scientific and Research Publications. 4(4): 1-5.

Naseer, S., Kashif, M., Ahmad, H.M. Iqbal, M.S., and Qurban Ali, Q. 2015. Estimation of genetic association among yield contributing traits in aromatic and non-aromatic rice (Oryza sativa L.) cultivars. Life Science Journal. 12(4): 6873.

Patel, J.R., Saiyad, M.R., Prajapati, K.N., Patel, R.A and Bhavani, R.T. 2014. Genetic variability and character association studies in rainfed upland rice (Oryza sativa L.). Electronic Journal of Plant Breeding. 5(3): 531-537.

Rahman, M.A., Hossain, M.S., Chowdhury, I.F., Matin, M.A and Mehraj, H. 2014. Variability study of advanced fine rice with correlation, path co-efficient analysis of yield and yield contributing characters. International Journal of Applied Science and Biotechnology. 2(3): 364-370.

Rajamadhan, R., Eswaran, R and Anandan, A. 2011. Investigation of correlation between traits and path analysis of rice (Oryza sativa L.) grain yield under coastal salinity. Electronic Journal of Plant Breeding. 2(4): 538-542.

Rajendra Prasad, K., Radha Krishna, K.V., Sudheer Kumar, S., Senguttuvel, P., and Subba Rao, L.V. 2017. Character Association and Path Analysis studies for Quantitative Traits in Hybrid Rice (Oryza sativa L.). International Journal of Pure and Applied Bioscience. 5(4): 1513-1518.

Ranawake, A.L and Amarasinghe, U.G.S. 2014. Relationship of yield and yield related traits of some traditional rice cultivars in Sri Lanka as described by correlation analysis. Journal of Scientific Research \& Reports. 3(18): 2395-2403.

Rao, V.T., Mohan, Y.C., Bhadru, D., Bharathi, D and Venkanna, V. 2014. Genetic variability and association analysis in rice. International Journal of Applied Biology and Pharmaceutical Technology. 5(2): 63-65. 
Ratna, M., Begum, S., Husna, A., Dey, S.R and Hossain, M.S. 2015. Correlation and path coefficients analyses in basmati rice. Bangladesh Journal of Agricultural Research.40(1): 153-161.

Ravindra Babu, V., Shreya, K., Kuldeep S.D., Usharani, G., Siva Shankar, A. 2012. Correlation and Path Analysis Studies in Popular Rice Hybrids of India. International Journal of Scientific and Research Publications. 2(3).dra.

Reddy, G.E., Suresh, B.G., Sravan, T and Reddy, P.A. 2012. Interrelationship and cause-effect analysis of rice genotypes in North East plain zone. The Bioscan. 8(4): 1141-1144.

Satish Chandra, B., Dayakar Reddy, T., Sudheer Kumar, S. 2009. Variability parameters for yield, its components and quality traits in rice. Crop Research. 38(1/3): 144-146.

Seyoum, M., Alamerew, S and Bantte, K. 2012. Genetic Variability, Heritability, Correlation Coefficient and Path Analysis for Yield and Yield Related Traits in Upland Rice (Oryza sativa L.). Journal of Plant Sciences. 7(1): 13-22.

Sheeba, N.K., Viraktamath, B.C., Sivaramakrishnan, S., Gangashetti, M.G., Khera, P and Sundaram, R.M. 2009. Validation of molecular markers linked to fertility restorer gene(s) for WA-CMS lines of rice. Euphytica. 167: 217-227.

Snedecor, G.W and Cochran, W.G., Statistical methods. 6th edition Iowa State University Press, Ames Iowa (1967).

Souroush HR, Mesbah M, Hossainzadeh A and Bozorgipour R. 2004. Genetic and phenotypic variability and cluster analysis for quantitative and qualitative traits of rice. Seed and Plant. 20 (2): 167-182.

Sowmiya, C.A., and Venkatesan, M. 2017. Studies on Correlation and Path Coefficient Analysis in Rice (Oryza Sativa L.). International Journal of Current Microbiology and Applied Sciences. 6(9): 1757-1763.

Srijan, A., Sudheer Kumar, S., Damodar Raju, Ch., Jagadeeshwar, R. 2016. Character association and path coefficient analysis for grain yield of parents and hybrids in rice (Oryza sativa L.). Journal of Applied and Natural Science.8 (1): 167 -172.

Srikanth, T., Sudheer Kumar, S., Senguttuvel, P., Sheshu Madhav, M. 2017. Correlation Analysis for Yield and Yield Components in Rice (Oryza sativa L.). International Journal of pure and Applied Bioscience. 5 (4): 1412-1415.

Touhiduzzaman, S., Asif, R.K., Mehraj, H, Jamal Uddin. 2016. Correlation and Genetic Distance on Sixteen Rice Varieties Grown Under SRI. Advances in Plants \& Agriculture Research. 3(3): 00100.

Virmani, S.S., Mao, C.X. and Hardy, B. 2003. Hybrid Rice for Food Security, Poverty Alleviation, and Environmental Protection. Proceedings of the 4th International Symposium on Hybrid Rice, Hanoi, Vietnam, 14-17 May 2002. Los Baños (Philippines), IRRI. 407.

Wright, S. 1921. Correlation and causation. Journal of Agricultural Research. 20: 257-87.

\section{How to cite this article:}

Kiranmayee B., Ch. Damodar Raju, K. B. Kempa Raju and Balaram, M. 2018. A Study on Correlation and Path Coefficient Analysis for Yield and Yield Contributing Traits in Maintainer (B lines) Lines of Hybrid Rice (Oryza sativa L.). Int.J.Curr.Microbiol.App.Sci. 7(06): 2918-2929. doi: https://doi.org/10.20546/ijcmas.2018.706.343 